\title{
高校生・大学生の食行動に影響を与える食物嗜好及び 社会心理的要因に関する研究
}

\author{
笠 巻 純 一 \\ 新潟大学人文社会・教育科学系
}

\section{Study of the Dietary Preferences and the Social-Psychological Factors that Affect the Dietary Behaviors of High School and University Students}

\author{
Junichi KASAMAKI \\ Institute of Humanities, Social Sciences and Education, Niigata University
}

\begin{abstract}
Objectives: This study was conducted to elucidate the correlation among dietary intake, dietary preferences, and social-psychological factors in the youth and to examine the factors that affect such dietary behaviors as snacking, skipping breakfast, and taking a biased nutrition.

Methods: A survey was carried out using a questionnaire with closed questions on multiple items such as dietary behaviors, psychosocial stress, dietary externalization, information and consciousness about health. The survey was conducted on 1,056 high school students and 1,323 university students in Japan.

Results: As a result of the factor analysis among the groups of male/female and high school/university students, relationships were found between the items of "preferences for snacking" and "snack food intakes" among all these groups. Those who like sweets and snacks tended to snack between lunch and dinner or after dinner by themselves more often than those who do not.

In contrast to men, intermediate correlations were found between the item of "a meal as a diversion" and each of the items of "snack food intake," "preferences for fried foods/sautéed foods/meat dishes," and "preferences for snacking," among women who do not live alone, regardless of their being high school or university students.

The item of "stress over human relationships/academic performance" was shown to have similarly weak correlations with the items of "reasons for skipping breakfast" and "nutrition intake" in the groups of male and female high school students. The less they value nutrition intake, the more they tend to be conscious of stress over human relationships/academic performance.
\end{abstract}

Key words: dietary behaviors（食行動), dietary preferences（食物嗜好）, social-psychological factors（社会心理的要因),

high school and university students（高校生・大学生), questionnaire survey（質問紙調査）

I 緒 言

近年，食生活を取り巻く社会環境の変化に伴い，栄養 の偏り, 不規則な食事, 肥満や生活習慣病の増加など, 食と健康に関する諸問題が顕在化している。このような 状況のなかで，我が国に拈いては，平成 12 年に「21 世

受付 2012 年 5 月 23 日, 受理 2012 年 9 月 14 日

Reprint requests to: Junichi KASAMAKI

Department of Education, Niigata University, 8050, Ikarashi 2 no-cho, Nishi-ku, Niigata 950-2181, Japan

TEL: +81(25)262-7089, FAX: +81(25)262-7089

E-mail: jkasamaki@ed.niigata-u.ac.jp
紀に拈ける国民健康づくり運動（健康日本 21）」(1）が策 定され, 生活習慣病の一次予防に重点を置いた施策が実 施されているところである。さらに，平成 17 年には食育 基本法が施行され，国民の食生活の改善や食文化の継承 を図るための教育の推進が図られている。しかしながら, 現状として，男性の肥満者の割合，女性のやせ（低体重） の者の割合，朝食の欠食率，脂肪エネルギ一比率等につ いて，顕著な改善は見られていない(2)。青少年層の食 習慣に着目すると, 朝食の欠食率と脂肪エネルギ一比率 は，男女とも 20 歳代が最も高く（3）, 生活習慣病の一次 予防の観点から，さらなる食育・健康教育の推進が求め られる。健康教育に打いては，対象の生活習慣の実態を 
把握するとともに, 疾病のリスク要因と成り得る食行動 などに影響を与兄る要因を解明して，行動変容を促すた めの手法について検討することが重要である。

Shepherd（4）は，食物の選択・摂取に影響する要因と して, 食物の化学的 - 栄養的内容, 生理的効果, 感覚属 性, 心理的要因, 経済的・社会的環境, 態度などを挙げ ている。また，青年期に打ける食行動比関しては，個人 の内面の影響 (e.g. 社会心理的, 生物学的), 社会的環境 または対人関係 (e.g. 家族や仲間)，物理的環境またはコ ミュニティーの環境 (e.g. ファーストフード店, コンビ ニエンス・ストアー (以下, コンビニと表記), マクロシ ステムまたは社会（e.g. マスメディア，マーケティング と広告, 社会的・文化的な規範）の影響がモデルとして 提示されている(5)。わが国の青少年の食行動や食行動 飞影響を与える要因関しては, 居住形態と食生活 (6-9), 食物摂取々健康習慣汇関する意識, 知識, 態度 (10), 情 報源が食生活に与光る影響 (11), 食生活に及涪す欠食の 影響 (12)，ファーストフードの利用 (13)，コンビニの利 用 (14), 心理的要因と食行動 (15) 等についての研究が 見られる。食物嗜好も, 食物の消費パターンに影響を与 える要因である (16)。

このように，青少年の食行動に影響を与える要因に関 する報告が数多く見受けられるものの，わが国に执いて は, 高校生と大学生を対象に複数の要因の相互関係を分 析し, 食行動に影響を与兄る要因について検討した研究 は行われていない。青少年の食行動に影響を与兄る多要 因について解明することは，健全な食生活を育むための 健康教育及び食を取り巻く環境の改善を図るらえで有用 であると考兄られる。そこで，本研究では，高校生・大 学生を対象に食行動, 食物嗜好, 心理社会的ストレス, 食の外部化，健康に関する意識，情報的影響なぞ，多要 因の相互関係を明らかにし, 青少年の食行動に影響を与 える要因について検討を行った。

\section{II方法}

\section{1. 分析対象と調査方法}

調查対象は, 新潟県内の高校 5 校の生徒 1,056 人, 新 潟県内の大学 6 校の他, 新潟県外の大学 4 校（福島県 1 校, 山口県 1 校, 埼玉県 1 校, 京都府 1 校）の学生 1,323 人であった。調査は，無記名による多項目選択回答形式 による質問紙を用い，配票調查法によって行われた。質 問紙の回収は，著者または調査実施対象校の教員が行っ た。調査は, 平成 17 年 10 月から平成 18 年 1 月の間に実 施した。無回答を含むすべての質問紙を回収した後，有 効回答を集計・分析の対象とした。なお，全ての質問項 目に対して不備なく回答が記入されている質問紙を有効 回答として処理した。有効回答率（数）は, $90.8 \%(2,161$ 人）であった。表 1 飞男女別，年齢別の有効回答者数， 表 2 に分析対象者の平均年齢を示す。
表 1 質問紙の回収結果

\begin{tabular}{lccc}
\hline & 配票数 & 有効回答数 & 有効回答率 \\
\hline 高校生 & 1,056 & 950 & $90.0 \%$ \\
大学生 & 1,323 & 1,211 & $91.5 \%$ \\
\hline 総計 & 2,379 & 2,161 & $90.8 \%$ \\
\hline
\end{tabular}

\section{表 2 分析対象者の年齢}

\begin{tabular}{ccc}
\hline & Mean & SD \\
\hline 高校生男子 $(\mathrm{n}=401)$ & 16.22 & 0.80 \\
高校生女子 $(\mathrm{n}=549)$ & 16.12 & 0.77 \\
大学生男子 $(\mathrm{n}=509)$ & 19.95 & 1.70 \\
大学生女子 $(\mathrm{n}=702)$ & 19.34 & 1.14 \\
\hline
\end{tabular}

\section{2. 倫理的配慮}

調査は，著者または調查実施対象校の教員が調査対象 者に以下の説明を行い，協力依頼に対して賛同した者を 対象とした。調査対象者には，本研究が青少年に対する 健康教育の開発の一助とすることを目的に行われるもの であること，無記名による調査であること，データの処 理に扮いては個人を特定しないこと，調査対象となる集 団の所属や学校名は公表しないこと，学力・能力などを 試すものではないことを書面で説明した。なお，調査実 施対象校の教員への依頼にあたっては，研究概要及び調 査票（案）を事前に配布して説明するとともに，調査協 力が任意であることを口頭で説明し承諾を得た後，本調 査で使用する質問紙を送付した。

\section{3. 分析方法}

因子分析を用いてカテゴリ一別に主要因子を抽出し， 下位尺度を検討した。信頼性分析を行い各尺度の内的整 合性を確認した。カテゴリ一別に項目を得点化し，複数 項目からなる尺度については尺度得点，単一項目につい ては項目の得点について，各々，平均值と標準偏差を算 出した。さらに, 学校種別と性別の要因の主効果を確認 するため， 2 元配置分散分析（必要に応じて単純主効果 の検定）を行った。2 元配置分散分析及び単純主効果の 検定の有意水準は，.05 未満を基準とした。また，因子分 析を行い要因（項目）間の相関構造について検討した。 な拈，因子分析を行らにあたり，KMO の標本妥当性の 検定を行い観測変数を使用して分析を施すことの妥当性 を確認するとともに, Bartlett の球面性検定を行い観測変 数間に関連性があることを確認した。

因子分析においては，主因子法を用いバリマックス法 による回転解を求めた。尺度の検討においては，因子分 析の結果，複数の因子にわたって因子負荷の高い項目及 び共通性の低い項目を除外するとともに，因子寄与の最 も高い因子を中心に因子負荷が絶対值 .30 以上（小数点 第 3 位を四捨五入）を示す項目を選出した。因子分析に おける因子の下限は，固有值 1 以上を基準とした。分析 には，統計ソフトSPSS16.0J for Windows を用いた。 


\section{4. 調査項目}

性, 年齢, 居住形態の他, 先行研究 (4-17) を参考に食 行動及び青少年の食行動との関連が予測される要因を検 討し, 「栄養・食生活」,「欠食理由」,「インスタント食品 摂取理由」,「コンビニ食・ファーストフード摂取理由」, 「食物嗜好」，「間食摂取」，「心理社会的ストレス」，「食・ 栄養・医療など健康に関する情報」,「食行動と疾病の関 連性についての意識」など, 合計 74 の質問項目を作成し た（付表 1-1，1-2）。各質問に対して 5 件法で回答を求め た。「栄養・食生活」の項目の一部は, American Running and Fitness Association の健康度評価尺度 (17) を改変して 作成した。な拈, 本調查に先立ち, 高校生 112 人, 大学 生 176 人に対して, 予備調查を実施し, テスト自体のも つ要因（質問内容の表現法, 語彙の選択, テスト項目の 困難度, 回答パターンの系統性等) 及び被験者の要因 (テ ストに対する反発，不安）の各観点から妥当性を検討し 修正を加光た。

\section{5. 食行動関連因子に関する分析項目の選定}

栄養・食生活に関する 13 項目について, 因子分析を施 し項目を検討した。因子分析の結果, 第 1 因子に 8 項目 (「栄養バランス」, 「家庭料理（朝食）」, 「家庭料理（夕 食) 」, 「朝食摂取」,「栄養摂取一の配慮」,「家庭料理（昼 食) 」,「和食摂取」,「インスタント食品摂取」）が抽出さ れた。8項目について, 同様の因子分析を繰り返した結 果，1 因子の及が抽出された。上記 8 項目の因子負荷は 順に.65, .63，.58,.52,.48,.47,.37，.36を示した（因 子寄与 : 2.14$)$ 。なお，信頼性係数は $\alpha=.73$ であった。こ れらの項目を高校生・大学生の栄養摂取尺度とした。

欠食理由に関する 6 項目について, 因子分析を施し項 目を検討した。因子分析の結果, 第 1 因子に 4 項目（「忙 しい」, 「起床時間が遅い」,「(朝食の) 用意が面倒」,「食 欲がない」）が抽出された。4項目について，同様の因子 分析を繰り返した結果，1 因子の久が抽出された。上記 4 項目の因子負荷は順に.92，.86，.82，.75 を示した（因 子寄与 : 2.82 )。なお, 信頼性係数は $\alpha=.90$ であった。こ 孔らの項目を高校生・大学生の欠食理由尺度とした。

インスタント食品及びコンビニ食・ファーストフード 摂取理由に関する 12 項目について, 因子分析を施し項目 を検討した。因子分析の結果, 第 1 因子に 4 項目（「栄養 (コンビニ食・ファーストフード)」,「味覚（インスタン 卜食品) 」, 「味覚 (コンビニ食・ファーストフード) 」, 「栄 養（インスタント食品）」）が抽出された。4 項目につい て, 同様の因子分析を繰り返した結果, 1 因子のみが抽 出された。上記 4 項目の因子負荷は順に.71，.65，.65, .64 を示した（因子寄与：1.76）。な拈，信頼性係数は $\alpha=.76$ であった。これらの項目を高校生・大学生のイン スタント食品・コンビニ食・ファーストフード摂取理由 （表中では, インスタント食品・ファーストフード摂取理 由と表記）尺度とした。

食物の嗜好性に関する 6 項目について，因子分析を施
乙項目を検討した。因子分析の結果，第 1 因子に 3 項目 (「揚げ物・炒め物」,「肉料理」，「間食」）が抽出された。 3 項目について, 同様の因子分析を繰り返した結果, 1 因 子のみが抽出された。上記 3 項目の因子負荷は順に .79, $.73 ． 30$ を示した（因子寄与：1.25）。こ北らの項目を高 校生・大学生の食物の嗜好性を示寸主要項目とした。3 項目の内, とりわけ「揚げ物・炒圽」,「肉料理」の因 子負荷が高い值を示したことから，「揚壮物・炒め物」， 「肉料理」の 2 項目を揚げ物・炒め物・肉料理の嗜好尺度 とした $(\alpha=.73)$ 。な拉，「間食」の項目は，「揚げ物・炒 め物」,「肉料理」の項目浪ど高い因子負荷を示さなかっ たものの，第 1 因子に. 30 以上の因子負荷を示したこと から，分析項目として取り扱らこととした。

間食摂取に関する 12 項目について, 因子分析を施し項 目を検討した。因子分析の結果，第 1 因子に 5 項目（「間 食の癖」,「空腹時の間食」,「午後の間食」,「夜の間食」, 「一人での間食」）が抽出された。5項目について, 同様 の因子分析を繰り返した結果，1因子の久が抽出された。 上記 5 項目の因子負荷は順に $.80, .71, .70, .66, .53$ を 示した（因子寄与 : 2.33 )。な拈，信頼性係数は $\alpha=.81$ で あった。これらの項目を高校生・大学生の間食拱取尺度 とした。

心理社会的ストレスに関する 13 項目について, 因子分 析を施し項目を検討した。因子分析の結果, 第 3 因子 (寄 与率 5.1\%）飞抽出された項目を除外し，11 項目（対人 （友人）ストレス, 対人 (社会活動) ストレス, 学業面で のストレス, 対人 (先生) ストレス, 対人 (家族) スト レス，生活リズムに対するストレス，生活環境に対する ストレス, 対人 (部活動) ストレス, 進路ストレス, 将 来ストレス，家計ストレス）を選出した。上記 11 項目に ついて，因子分析を施した結果，第 1 因子に 8 項目（「対 人（友人）ストレス」,「対人 (社会活動) ストレス」,「学 業面でのストレス」,「対人 (先生) ストレス」,「対人 (家 族）ストレス」,「生活りズムに対するストレス」,「生活 環境に対するストレス」,「対人（部活動）ストレス」）が 抽出された。8 項目について, 同様の因子分析を繰り返 した結果， 1 因子のみが抽出された。上記 8 項目の因子 負荷は順に $.67, .65, .59, .59, .56, .54, .51 ， .46$ を示し た（因子寄与：2.66）。なお，信頼性係数は $\alpha=.80$ であっ た。これらの項目を高校生・大学生の対人関係・学業ス トレス尺度とした。

健康に関する情報源に関する 8 項目について，因子分 析を施し項目を検討した。因子分析の結果，第 1 因子に 5 項目 (「書籍」,「インターネット」,「新聞」,「テレビ・ ラジオ」,「保健・医療・健康増進施設」）が抽出された。 5 項目について, 同様の因子分析を繰り返した結果, 1 因 子の久が抽出された。上記 5 項目の因子負荷は順に.75, $.64 ， .64 ， .54 ， .46$ を示した（因子寄与：1.88）。な拈，信 頼性係数は $\alpha=.74$ であった。これらの項目を高校生・大 学生の健康㳊関する情報源尺度（以下, 健康情報尺度) とした。 
本研究では, 先行研究において, 体脂肪蓄積 (18) や健 康状態 $(1,19,20)$ との関係が指摘されている栄養摂取状 沉の偏り，喫煙・飲酒・運動習慣等とともに死亡率との 関係が示唆されている間食及び欠食 (21) の 3 要因（偏 食，間食，欠食）を取り上げた。「欠食による罹患」，「偏 食による罹患」，「間食による罹患」の3 項目について因 子分析を行った結果, 1 因子のみが抽出された。上記 3 項 目の因子負荷は順に .85，.63，.59を示した（因子寄与： 1.46）。なお，信頼性係数は $\alpha=.72$ であった。これらの 項目を食行動と疾病の関連意識尺度とした。

なお，上記 8 尺度のクロンバックの $\alpha$ 係数は，いずれ も.70 以上を示し，概ね十分な内的整合性が確認された。

\section{III 結 果}

\section{1. 学校種別及び性別による主効果の検定}

尺度を構成する項目の合計得点を各尺度の尺度得点と した。栄養掑取尺度, 欠食理由尺度, インスタント食品・ コンビニ食・ファーストフード摂取理由尺度, 揚げ物・ 炒め物 - 肉料理の嗜好尺度, 間食摂取尺度, 対人関係・ 学業ストレス尺度, 健康情報尺度, 食行動と疾病の関連 意識尺度の各尺度得点及び間食の嗜好に関する項目，食 事による気分転換に関する項目の各項目得点について, 各々平均值と標準偏差を求めた。さらに, 各食行動関連
要因について，学校種別及び性別の 2 要因による主効果 の検定を行った。表 3 は，尺度得点及び項目得点の平均 值と標準偏差，主効果の検定結果を示したものである。

間食の嗜好得点の平均值は，高校生の男性 3.40，女性 4.00, 大学生の男性 3.36, 女性 4.02 を示し, 性別の要因 に主効果が認められた $\left(F_{1,2157}=160.45, \mathrm{p}<.001\right)$ 。

間食摄取得点の平均值は，高校生の男性 13.38，女性 15.72，大学生の男性 13.88，女性 16.14 を示し，学校種別 及び性別の要因に主効果が認められた（各々， $F_{1,2157}=$ $\left.4.74, \mathrm{p}=.030, \quad F_{1,2157}=117.20, \mathrm{p}<.001\right) 。$

インスタント食品・コンビニ食・ファーストフード摂 取理由得点の平均值は，高校生の男性 9.77, 女性 11.06, 大学生の男性 9.65 , 女性 10.42 を示し，学校種別及び性 別の要因に主効果が認められた（各々， $F_{1,2157}=6.06$, $\left.\mathrm{p}=.014, \quad F_{1,2157}=43.45, \mathrm{p}<.001\right) 。$

栄養摂取得点の平均值は，高校生の男性 31.19, 女性 31.00, 大学生の男性 25.03, 女性 27.88 を示した。学校種 別，性別いずれの要因も有意であったが（各々， $F_{1,2157}=$ $\left.366.97, \mathrm{p}<.001, F_{1,2157}=30.02, \mathrm{p}<.001\right), 2$ 要因に交互 作用が確認された $\left(F_{1,2157}=39.27, \mathrm{p}<.001\right)$ 。

欠食理由得点の平均值は, 高校生の男性 6.96, 女性 7.04，大学生の男性 11.04，女性 9.25 を示した。学校種 別，性別いずれの要因も有意であったが（各々， $F_{1,2157}$ $\left.=220.96, \mathrm{p}<.001, F_{1,2157}=16.37, \mathrm{p}<.001\right), 2$ 要因に交

表 3 食行動関連要因の得点と効果の検定結果

\begin{tabular}{|c|c|c|c|c|c|c|c|c|}
\hline & & \multicolumn{2}{|c|}{ 高校生 } & \multicolumn{2}{|c|}{ 大学生 } & \multirow{2}{*}{ 学校種別 } & \multirow{2}{*}{ 性別 } & \multirow{2}{*}{$\begin{array}{l}\text { 学校種別 } \\
\quad \times \text { 性別 }\end{array}$} \\
\hline & & 男（n=401） & 女 $(n=549)$ & 男（n=509） & 女 $(n=702)$ & & & \\
\hline \multirow{2}{*}{ 間食の嗜好 } & Mean & 3.40 & 4.00 & 3.36 & 4.02 & & \multirow{2}{*}{$* * *$} & \\
\hline & $\mathrm{SD}$ & 1.27 & 1.07 & 1.22 & 1.02 & & & \\
\hline \multirow{2}{*}{ 間食摂取 } & Mean & 13.38 & 15.72 & 13.88 & 16.14 & \multirow{2}{*}{$*$} & \multirow{2}{*}{$* * *$} & \\
\hline & SD & 5.15 & 4.68 & 5.15 & 4.53 & & & \\
\hline \multirow{2}{*}{$\begin{array}{l}\text { インスタント食品・ファー } \\
\text { ストフード掑取理由 }\end{array}$} & Mean & 9.77 & 11.06 & 9.65 & 10.42 & \multirow{2}{*}{$*$} & \multirow{2}{*}{$* * *$} & \\
\hline & $\mathrm{SD}$ & 3.88 & 3.53 & 3.42 & 3.50 & & & \\
\hline \multirow{2}{*}{ 栄養摂取 } & Mean & 31.19 & 31.00 & 25.03 & 27.88 & \multirow{2}{*}{$* * *$} & \multirow{2}{*}{$* * *$} & \multirow{2}{*}{$* * *$} \\
\hline & SD & 4.85 & 4.85 & 6.20 & 5.85 & & & \\
\hline \multirow{2}{*}{ 欠食理由 } & Mean & 6.96 & 7.04 & 11.04 & 9.25 & \multirow{2}{*}{$* * *$} & \multirow{2}{*}{$* * *$} & \multirow{2}{*}{$* * *$} \\
\hline & $\mathrm{SD}$ & 4.34 & 4.31 & 5.40 & 5.03 & & & \\
\hline \multirow{2}{*}{ 対人関係・学業ストレス } & Mean & 19.93 & 22.58 & 20.85 & 21.77 & & \multirow{2}{*}{$* * *$} & \multirow{2}{*}{$* *$} \\
\hline & SD & 7.10 & 6.17 & 6.23 & 5.90 & & & \\
\hline \multirow{2}{*}{$\begin{array}{l}\text { 揚げ物・炒め物・肉料理の } \\
\text { 若好 }\end{array}$} & Mean & 8.20 & 7.58 & 8.10 & 7.53 & & \multirow{2}{*}{$* * *$} & \\
\hline & SD & 1.48 & 1.69 & 1.66 & 1.77 & & & \\
\hline \multirow{2}{*}{ 食事による気分転換 } & Mean & 3.03 & 3.32 & 3.01 & 3.61 & \multirow{2}{*}{$*$} & \multirow{2}{*}{$* * *$} & \multirow{2}{*}{ ** } \\
\hline & $\mathrm{SD}$ & 1.28 & 1.18 & 1.30 & 1.13 & & & \\
\hline \multirow{2}{*}{ 健康情報 } & Mean & 11.92 & 12.26 & 13.04 & 13.55 & \multirow{2}{*}{$* * *$} & \multirow{2}{*}{$*$} & \\
\hline & SD & 4.31 & 4.18 & 4.22 & 4.04 & & & \\
\hline \multirow{2}{*}{ 食行動と疾病の関連意識 } & Mean & 11.38 & 11.64 & 12.01 & 12.13 & $* * *$ & & \\
\hline & SD & 2.64 & 2.23 & 2.49 & 2.10 & & & \\
\hline
\end{tabular}

$* \mathrm{p}<.05 * * \mathrm{p}<.01 * * * \mathrm{p}<.001$ 


\begin{tabular}{|c|c|c|c|c|}
\hline \multirow{2}{*}{ 項 } & \multicolumn{4}{|c|}{ バリマックス解 } \\
\hline & $\mathrm{F} 1$ & $\mathrm{~F} 2$ & F3 & F4 \\
\hline 1. 間食の嗜好 & .733 & -.022 & .216 & -.121 \\
\hline 2. 間食摂取 & .698 & .152 & .042 & .018 \\
\hline 3. インスタント食品・ファーストフード拱取理由 & .408 & .117 & .078 & .086 \\
\hline 4. 栄養摂取 & -.136 & -.883 & .010 & .125 \\
\hline 5. 欠食理由 & .030 & .556 & -.039 & -.056 \\
\hline 6. 対人関係・学業ストレス & .219 & .300 & -.032 & .204 \\
\hline 7. 揚げ物・炒め物・肉料理の嗜好 & .140 & -.020 & .742 & .003 \\
\hline 8. 食事による気分転換 & .230 & -.038 & .266 & .190 \\
\hline 9. 健康情報 & .006 & -.042 & .034 & .532 \\
\hline 10. 食行動と疾病の関連意識 & -.185 & -.091 & .144 & .166 \\
\hline 因子の寄与 & 1.365 & 1.229 & .701 & .430 \\
\hline
\end{tabular}

$\mathrm{n}=401$

表 4-2 男子大学生の食行動関連因子に関する因子分析結果

\begin{tabular}{|c|c|c|c|c|}
\hline \multirow{2}{*}{ 項 } & \multicolumn{4}{|c|}{ バリマックス解 } \\
\hline & F1 & $\mathrm{F} 2$ & F3 & F4 \\
\hline 1. 間食の嗜好 & .894 & -.024 & -.030 & .128 \\
\hline 2. 間食摂取 & .619 & -.039 & .313 & -.131 \\
\hline 3. インスタント食品・ファーストフード拱取理由 & .341 & .012 & .247 & .059 \\
\hline 4. 栄養搷取 & -.063 & .818 & -.059 & .089 \\
\hline 5. 欠食理由 & .056 & -.733 & .203 & -.093 \\
\hline 6. 健康情報 & .085 & .289 & .196 & -.114 \\
\hline 7. 食事による気分転換 & .128 & .055 & .584 & .200 \\
\hline 8. 対人関係・学業ストレス & .062 & -.100 & .325 & .052 \\
\hline 9. 揚げ物・炒め物・肉料理の嗜好 & .281 & -.093 & .185 & .743 \\
\hline 10. 食行動と疾病の関連意識 & -.082 & .089 & .049 & .166 \\
\hline 因子の寄与 & 1.418 & 1.321 & .726 & .689 \\
\hline
\end{tabular}

$\mathrm{n}=509$

互作用が確認された $\left(F_{1,2157}=19.62, \mathrm{p}<.001\right)$ 。

対人関係・学業ストレス得点の平均値は, 高校生の男 性 19.93, 女性 22.58, 大学生の男性 20.85, 女性 21.77 を 示した。性別の要因に有意差が認められたものの $\left(F_{1,2157}\right.$ $=42.09, \mathrm{p}<.001), 2$ 要因に交互作用が確認された $\left(F_{1,2157}\right.$ $=9.94, \mathrm{p}=.002)$ 。

揚げ物・炒め物・肉料理の嗜好得点の平均值は, 高校 生の男性 8.20, 女性 7.58, 大学生の男性 8.10, 女性 7.53 を示し, 性別の要因に主効果が認められた $\left(F_{1,2157}=\right.$ $66.11, \mathrm{p}<.001)$ 。

食事による気分転換得点の平均值は，高校生の男性 3.03, 女性 3.32, 大学生の男性 3.01, 女性 3.61 を示し, 学校種別, 性別いずれの要因も有意であったが（各々, $\left.F_{1,2157}=6.73, \mathrm{p}=.010, F_{1,2157}=71.15, \mathrm{p}<.001\right), 2$ 要因 に交互作用が確認された $\left(F_{1,2157}=8.34, \mathrm{p}=.004\right)$ 。

健康情報得点の平均值は, 高校生の男性 11.92, 女性 12.26, 大学生の男性 13.04, 女性 13.55 を示し, 学校種別 及び性別の要因に主効果が認められた（各々， $F_{1,2157}=$ $\left.43.71, \mathrm{p}<.001, F_{1,2157}=5.41, \mathrm{p}=.020\right)$ 。

食行動と疾病の関連意識得点の平均值は, 高校生の男
性 11.38, 女性 11.64, 大学生の男性 12.01, 女性 12.13 を 示し, 学校種別の要因に主効果が認められた（ $F_{1,2157}=$ $29.72, \mathrm{p}<.001)$ 。

\section{2. 食行動関連要因の分析}

\section{（1）間食の嗜好，間食摂取関連因子}

因子分析の結果選出された 8 尺度（栄養摂取，欠食理 由, インスタント食品・コンビニ食・ファーストフード 摂取理由, 揚げ物・炒め物・肉料理の嗜好, 間食摂取, 対人関係・学業ストレス, 健康情報, 食行動と疾病の関 連意識）及び間食の嗜好，食事による気分転換の 2 項目 の各得点を用いて性・学校種別，大学生に抢いては性・ 居住形態別 (一人暮らしの者, 一人暮らしではない者 (以 下，非一人暮らし））に因子分析を行った。因子分析の結 果については，抽出されたすべての因子を表（表 4-1〜 表 4-8）に示した。以下，因子分析の結果，因子の寄与 が 1.00 以上の因子に打いて，因子負荷が絶対值 .30 以上 を示した項目について記す（表 4-1～表 4-8 においては， 絶対值 .40 以上の因子負荷を太字で示した)。

男子高校生, 男子大学生を対象とした因子分析の結果, 


\begin{tabular}{|c|c|c|c|}
\hline \multirow{2}{*}{ 項 } & \multicolumn{3}{|c|}{ バリマックス解 } \\
\hline & F1 & F2 & F3 \\
\hline 1. 間食の嗜好 & .869 & -.024 & -.145 \\
\hline 2. 間食摂取 & .583 & .202 & .217 \\
\hline 3. 食事による気分転換 & .463 & .053 & .389 \\
\hline 4. 揚げ物・炒め物・肉料理の嗜好 & .403 & -.111 & -.013 \\
\hline 5. インスタント食品・ファーストフード撕取理由 & .327 & .128 & .083 \\
\hline 6. 栄養摂取 & -.156 & -.874 & .088 \\
\hline 7. 欠食理由 & -.030 & .617 & -.029 \\
\hline 8. 対人関係・学業ストレス & .198 & .314 & .262 \\
\hline 9．健康情報 & -.039 & -.030 & .400 \\
\hline 10. 食行動と疾病の関連意識 & .083 & -.160 & .170 \\
\hline 因子の寄与 & 1.651 & 1.343 & .493 \\
\hline
\end{tabular}

$\mathrm{n}=549$

表 4-4 女子大学生の食行動関連因子に関する因子分析結果

\begin{tabular}{|c|c|c|c|}
\hline \multirow{2}{*}{ 項 } & \multicolumn{3}{|c|}{ バリマックス解 } \\
\hline & F1 & $\mathrm{F} 2$ & F3 \\
\hline 1. 間食の嗜好 & .744 & .048 & -.143 \\
\hline 2. 間食摂取 & .688 & -.030 & -.039 \\
\hline 3. 食事による気分転換 & .424 & -.056 & .172 \\
\hline 4. 揚げ物・炒め物・肉料理の嗜好 & .398 & -.050 & -.045 \\
\hline 5. インスタント食品・ファーストフード拱取理由 & .284 & -.132 & .130 \\
\hline 6. 栄養摂取 & -.121 & .857 & .143 \\
\hline 7. 欠食理由 & .025 & -.671 & -.086 \\
\hline 8． 健康情報 & -.017 & .167 & .474 \\
\hline 9. 対人関係・学業ストレス & .152 & -.142 & .342 \\
\hline 10. 食行動と疾病の関連意識 & -.045 & .080 & .192 \\
\hline 因子の寄与 & 1.487 & 1.265 & .477 \\
\hline
\end{tabular}

$\mathrm{n}=702$

\section{表 4-5 男子大学生（一人暮らし）の食行動関連因子に関する因子分析結果}

\begin{tabular}{|c|c|c|c|c|c|}
\hline \multirow{2}{*}{ 項 } & \multicolumn{5}{|c|}{ バリマックス解 } \\
\hline & F1 & F2 & F3 & $\mathrm{F} 4$ & F5 \\
\hline 1. 間食の嗜好 & .908 & -.029 & .053 & .244 & -.016 \\
\hline 2. 間食摂取 & .587 & -.133 & .456 & -.161 & .066 \\
\hline 3. 栄養摂取 & -.135 & .814 & -.011 & .016 & .048 \\
\hline 4. 欠食理由 & .003 & -.670 & .129 & .033 & .038 \\
\hline 5. 食事による気分転換 & .058 & .067 & .617 & .106 & -.011 \\
\hline 6. インスタント食品・ファーストフード摂取理由 & .246 & -.045 & .367 & .123 & -.166 \\
\hline 7. 対人関係・学業ストレス & .035 & -.085 & .340 & .026 & .050 \\
\hline 8. 揚げ物・炒め物・肉料理の嗜好 & .180 & -.016 & .264 & .722 & .120 \\
\hline 9. 健康情報 & .087 & .260 & .201 & -.227 & .187 \\
\hline 10. 食行動と疾病の関連意識 & -.007 & .008 & -.006 & .059 & .617 \\
\hline 因子の寄与 & 1.293 & 1.211 & .969 & .691 & .468 \\
\hline
\end{tabular}

$\mathrm{n}=272$

各群の第 1 因子には,「間食の嗜好」,「間食拱取」,「イン スタント食品・コンビニ食・ファーストフード拱取理由」 の3 項目が抽出された（表4-1，表4-2）。

男子大学生（非一人暮らし）を対象とした因子分析の
結果，第 1 因子には，「間食の嗜好」「「間食掑取」,「イン スタント食品・コンビニ食・ファーストフード拱取理 由」,「揚げ物・炒め物・肉料理の嘫好」の 4 項目が抽出 された（表 4-6）。 
表 4-6 男子大学生（非一人暮らし）の食行動関連因子に関する因子分析結果

\begin{tabular}{|c|c|c|c|c|}
\hline \multirow{2}{*}{ 項 } & \multicolumn{4}{|c|}{ バリマックス解 } \\
\hline & F1 & $\mathrm{F} 2$ & F3 & F4 \\
\hline 1. 間食の嗜好 & .922 & -.040 & .051 & -.009 \\
\hline 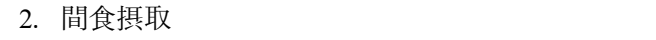 & .584 & .160 & .075 & .101 \\
\hline 3. インスタント食品・ファーストフード拱取理由 & .368 & .069 & .142 & .141 \\
\hline 4. 揚げ物・炒め物・肉料理の嗜好 & .322 & -.065 & .473 & -.185 \\
\hline 5. 欠食理由 & .099 & .852 & .084 & -.041 \\
\hline 6. 栄養摂取 & -.004 & -.678 & -.033 & .250 \\
\hline 7. 食行動と疾病の関連意識 & -.146 & -.307 & .273 & -.131 \\
\hline 8. 食事による気分転換 & .116 & .021 & .707 & .231 \\
\hline 9. 対人関係・学業ストレス & .056 & .195 & .250 & .027 \\
\hline 10．健康情報 & .088 & -.093 & .039 & .391 \\
\hline 因子の寄与 & 1.486 & 1.362 & .899 & .353 \\
\hline
\end{tabular}

$\mathrm{n}=237$

表 4-7 女子大学生（一人暮らし）の食行動関連因子に関する因子分析結果

\begin{tabular}{|c|c|c|c|c|c|}
\hline \multirow{2}{*}{ 項 } & \multicolumn{5}{|c|}{ バリマックス解 } \\
\hline & $\mathrm{F} 1$ & F2 & F3 & F4 & F5 \\
\hline 1. 間食摂取 & .874 & -.034 & .081 & .061 & .025 \\
\hline 2. 間食の嗜好 & .715 & .037 & .152 & .031 & -.116 \\
\hline 3. 栄養摂取 & -.113 & .922 & -.071 & -.073 & .123 \\
\hline 4. 欠食理由 & -.080 & -.627 & -.016 & .041 & -.176 \\
\hline 5. 揚げ物・炒め物・肉料理の嗜好 & .096 & .045 & .815 & .078 & -.018 \\
\hline 6. 食事による気分転換 & .271 & -.103 & .322 & -.002 & .149 \\
\hline 7. インスタント食品・ファーストフード拱取理由 & .065 & -.100 & .088 & .735 & -.041 \\
\hline 8． 食行動と疾病の関連意識 & -.005 & .084 & .061 & -.135 & .468 \\
\hline 9. 健康情報 & -.045 & .153 & -.011 & .198 & .360 \\
\hline 10. 対人関係・学業ストレス & .209 & -.228 & -.095 & .189 & .183 \\
\hline 因子の寄与 & 1.428 & 1.352 & .823 & .652 & .466 \\
\hline
\end{tabular}

$\mathrm{n}=236$

表 4-8 女子大学生（非一人暮らし）の食行動関連因子に関する因子分析結果

\begin{tabular}{|c|c|c|c|}
\hline \multirow{2}{*}{ 項 } & \multicolumn{3}{|c|}{ バリマックス解 } \\
\hline & $\mathrm{F} 1$ & F2 & F3 \\
\hline 1. 間食の嗜好 & .712 & .019 & -.122 \\
\hline 2. 間食摂取 & .645 & -.085 & -.041 \\
\hline 3. 食事による気分転換 & .466 & -.009 & .223 \\
\hline 4. 揚げ物・炒め物・肉料理の嗜好 & .464 & -.073 & -.097 \\
\hline 5. インスタント食品・ファーストフード摂取理由 & .343 & -.147 & .079 \\
\hline 6. 栄養摂取 & -.121 & .859 & .142 \\
\hline 7. 欠食理由 & .072 & -.637 & -.064 \\
\hline 8. 対人関係・学業ストレス & .118 & -.133 & .467 \\
\hline 9. 健康情報 & -.021 & .194 & .412 \\
\hline 10. 食行動と疾病の関連意識 & -.058 & .086 & .177 \\
\hline 因子の寄与 & 1.509 & 1.242 & .526 \\
\hline
\end{tabular}

$\mathrm{n}=466$

男子大学生（一人暮らし）, 女子大学生（一人暮らし） を対象とした因子分析の結果，各群の第 1 因子には，「間 食の嗜好」，「間食摂取」の 2 項目が抽出された（表 4-5, 表 4-7)。
女子高校生，女子大学生（非一人暮らし）を対象とした 因子分析の結果，各群の第 1 因子には，「間食の嗜好」，「間 食摂取」，「食事による気分転換」，「揚げ物・炒め物・肉料 理の嗜好」,「インスタント食品・コンビニ食・ファースト 
フード摂取理由」の 5 項目が抽出された（表 4-3, 表 4-8）。 女子大学生を対象とした因子分析の結果，第 1 因子に は，「間食の嗜好」，「間食摂取」，「食事による気分転換」， 「揚げ物・炒め物・肉料理の嗜好」の 4 項目が抽出された (表 4-4)。

性・学校種別, 性・学校種・居住形態別による因子分 析の結果, 第 1 因子に最も高い因子負荷を示した項目は, 「間食の嗜好」であった（因子負荷：.71〜.92）。次いで 高い値を示した項目は，「間食摂取」であり（因子負荷： $.58 \sim .87)$, 「間食の嗜好」の項目と正の相関が認められた。

\section{（2）栄養摂取，欠食理由関連因子}

男子高校生, 女子高校生を対象とした因子分析の結果, 各群の第 2 因子には，「栄養摂取」，「久食理由」，「対人関 係・学業ストレス」の 3 項目が抽出された（表 4-1, 表 4-3)。

男子大学生, 女子大学生, 男子大学生（一人暮らし）, 女子大学生（一人暮らし），女子大学生（非一人暮らし） を対象とした因子分析の結果, 各群の第 2 因子には,「栄 養摂取」,「欠食理由」の 2 項目が抽出された（表 4-2, 表 4-4，表 4-5，表 4-7，表 4-8）。

男子大学生（非一人暮らし）を対象とした因子分析の 結果，第 2 因子には，「欠食理由」，「栄養摂取」，「食行動 と疾病の関連意識」の3 項目が抽出された（表 4-6）。

性・学校種別, 性・学校種・居住形態別による因子分 析の結果，各群の第 2 因子には，「栄養摂取」（因子負荷 : 絶対值.68．92）と「欠食理由」（因子負荷：絶対值.56 〜 85）の 2 項目が比較的高い因子負荷を示した。なお， 「栄養摂取」と「欠食理由」は, すべての群に扎いて負の 相関を示した。

\section{IV 考察}

\section{1. 間食行動，食物嗜好，社会心理的要因の関連 （1）食物嗜好と間食行動}

高校生及び大学生の各男女別で因子分析を行った結 果，いずれの群に打いても「間食の嗜好」，「間食摂取」， 「インスタント食品・コンビニ食・ファーストフード摂取 理由」の項目間に関連性が認められた。とりわけ，「間食 の嗜好」と「間食摂取」の因子負荷が高く，中程度から 強い相関関係を示した。この結果から，扣菓子やスナッ ク類が好きな者ほど, 間食の頻度が高い傾向が示された。 また，これらの食物嗜好・間食行動は，既製品・外食に 対する意識と関連があることが示唆された。青少年の間 食行動・食物嗜好に関しては，「男女学生ともに嗜好重 視」（22）であること，10～20 歳代の若年層は洋風食品, スナック類, デザート類の好久值が高い (23) ことが指摘 されている。また，小学校 1 年生から高校生を対象とし たライフスタイルに関する調査からは，菓子類の食べ方 について，「何かをしながらお菓子を食べ続ける」は，年 齢と共にこの傾向が強くなる（24）ことが報告されてい る。ファーストフードの利用頻度に関しては,「小学生, 中学生に比べ高校生, 大学生の利用頻度が高かった $(\mathrm{p}<0.01) 」$ とる報告も見られる (13)。本研究において は，これらの食物嗜好，間食行動，食の外部化に関する 項目に関連が認められた。扣菓子・スナック類に対する 嗜好性や，コンビニやファーストフード店などで提供さ れる食品に対する意識が，高校生・大学生の間食頻度に 影響を与える要因となる可能性が考兄られた。

\section{（2）女子高校生及び女子大学生の間食行動と社会心理的}

\section{要因の関連}

因子分析の結果，女子高校生及び非一人暮らしの女子 大学生に扔いては，「間食の嗜好」，「間食摂取」，「食事に よる気分転換」，「揚げ物・炒め物・肉料理の嗜好」の 4 項目に関連が認められた。女子高校生と非一人暮らしの 女子大学生に扣いては，食べることを気分転換の手段に している者流ど, 間食の摂取頻度が高く, 扣菓子やスナッ ク類の他，揚げ物・炒め物等の高カロリー・高脂肪食を 好む傾向が強かった。高田ら（25）は，「食べるという行 為には，緊張を和らげるような精神安定作用がある」と して，心理的ストレスが誘因となる“気晴らし食い”な どの食行動について報告している。また，鈴江（26）は, ストレスが栄養素の必要量増加に関連することを指摘し ている。食物摂取と社会心理的要因の因果関係について は更なる調査と分析が必要であるが，女子高校生と非一 人暮らしの女子大学生を対象とした因子分析の結果から 示された「間食の嗜好」，「間食摂取」，「食事による気分 転換」，「揚げ物・炒め物・肉料理の嗜好」の 4 項目の関 連は，打菓子，スナック類，揚げ物，炒め物など，高力 ロリ一な嗜好食品の摂取と社会心理的要因の関係を示唆 する興味深い結果である。

因子分析の結果，中程度から強い相関を示した「間食 摂取」と「間食の嗜好」の各得点の性差をみると，高校 生，大学生いずれの群に㨟いても，女性の方が男性より も有意に高い值を示した。また，女子高校生，非一人暮 らしの女子大学生の「間食の嗜好」及び「間食摂取」に 関連する項目として抽出された「食事による気分転換」 も，女性の方が男性よりも高得点を示した。「間食の嗜 好」,「食事による気分転換」, いずれも間食行動の助長に 関連する要因と考兄られ，相加的に間食頻度の増加に影 響を与える可能性が示唆された。なお，「食事による気分 転換」の得点は，2 要因 (学校種別, 性別) 分散分析の 結果，交互作用が確認された。男，女の学校種別による 差の観点から単純主効果の検定を行らと，女性にの久有 意差が認められた（男性 $: p=.58$ ，女性 $: p<.001 ） 。 一$ 方，高校生，大学生の性別による差の観点から単純主効 果の検定を行らと，高校生，大学生いずれも男女に有意 差が認められた $(\mathrm{p}<.001)$ 。これらの結果から，分散分 析で示された交互作用は，女性の学校種別による得点差 が男女の学校種別の主効果に反映した結果であり，学校 種別にかかわらず，女性は男性よりも食べることで気分 転換を行ら傾向が強いと解釈される。

一人暮らしの女子大学生は，女子高校生及び非一人暮 らしの女子大学生とは若干異なる因子構造を示した。因 
子分析の結果，第 1 因子に打ける「食事による気分転換」 の因子負荷量は. 30 未満であり，「間食摂取」及び「間食 の嗜好」との関連は脆弱であった。また，「食事による気 分転換」之「揚げ物・炒め物・肉料理の嗜好」の関連を 示す因子が第 3 因子に抽出されたものの，その他の食行 動及び食物嗜好飞関する項目との関連は見られなかっ た。上記の因子構造の相違から, 居住形態は女子大学生 の食行動, 食物嗜好, 社会心理的要因の関連性に影響を 与える要因と成り得ることが示唆された。

\section{2. 高校生の栄養摂取・欠食と心理社会的ストレスの関連}

「対人関係・学業ストレス」の項目は, 男子高校生と女 子高校生の両群に打いて, 「栄養摂取」及び「久食理由」 の項目と弱い相関関係を示した。高校生においては，対 人関係・学業に関するストレス意識の高い者の方が,「忙 しい」,「起床時間が遅い」，「(朝食の) 用意が面倒」「「食 欲がない」といら理由で朝食を欠食することが多く, 栄 養バランスの評価や家庭料理の掑取頻度も低いことが明 らかとなった。これらの結果から, 朝食欠食, 家庭料理 の欠如，栄養バランスの乱れなどが，高校生における対 人関係及び学業に関するストレスと関連を有することが 示された。一方, 大学生は, 男, 女いずれも「栄養摂取」 と「欠食理由」の 2 項目に中程度から強い相関が見られ たものの, 両項目と「対人関係・学業ストレス」の項目 との関連は, 注とんど認められなかった。対人関係・学 業ストレスは, 特高校生の食生活に関連した要因であ ることが示唆された。

思春期のセルフエスティーム，ストレス対処スキルと 危険行動に関して川畑ら（27）は, 「朝食を毎日食べてい る，体育の授業以外飞週に 3 日以上運動を実施している といった健康的な行動を実践している生徒は，不健康な 行動を取っている生徒に比べてセルフエスティームおよ び積極的なストレス対処スキルの得点が高かった」とし て, 朝食搷取等の健康行動がセルフエスティームとス卜 レス対処スキルに関係していることについて指摘してい る。また, 小学生を対象とした研究からは,「社会的スキ ル（対人関係スキル）では, 朝食を毎日食べる者は食べ ない日がある者に比べて，好ましい「向社会的スキル」 の得点が高く, 好ましくない「引っ込久思案行動」と「攻 撃的行動」の得点が低かった」（28）とする報告も見られ る。さらに, 朝食欠食は, 認知機能だけでなく, 試験 (学 業）の成績への影響も示唆されている要因である（29）。 本研究の結果から, 栄養バランス・朝食欠食状況と対人 関係・学業成績の因果関係を示すことはできないが，対 人関係や学業に関するストレス意識への影響を示唆する 興味深い結果が示された。

\section{3. 間食行動に影響する要因を考慮した健康教育}

「間食を摄取しない」ことは，「朝食を摂取する」，「喫 煙をしない」「規則正しい運動」，「節度のある飲酒又は 飲酒をしない」,「1 日に $7 〜 8$ 時間の規則正しい睡眠」,
「適正体重の維持」とともに, 死亡率の低下に関連する要 因であり（21），青少年に対する生活習慣病の一次予防を 目的とした健康教育に捯いて重視すべき内容である。医 師や管理栄養士等の専門家による保健指導に基づく間食 や食事制限等，健康管理上，食事の回数と量の調整が必 要な場合もあるが，エネルギー所要量の超過や偏食につ ながる不適切な間食行動は控えるべきであるら。

本研究においては, 間食行動と間食の嗜好に関連が認 められ，食の嗜好性が間食行動㳘響していることが示 唆された。また，女子高校生と非一人暮らしの女子大学 生に打いては, 気分転換としての食行動が間食に影響し ている可能性が示唆された。間食を気分転換の手段とし ている者が，打菓子やスナック類の摂取を抑制する過程 に执いては，好みの食品（敃菓子・スナック類）を摂取 できないことや，気分転換の手段を失うことによるスト レスの増大が懸念される。したがって，技菓子・スナッ ク類の嗜好性が高く, 間食が習慣化している生徒・学生 に対しては，自発的な行動変容を促すためのアプローチ を検討する必要があると考兄る。

Prochaska ら（30）は，行動変容が一連のステージを経 て進んでいくことについて報告している。Prochaskaら （31）は, 高脂肪食の減少に向けたダイエットを含む12 種 類の行動について検討し，無関心期にある（少なくとも 6 力月以内に行動変容の意図がない）者は, 変化（ダイ エットをすること）に対するPros（恩恵）よりもCons （損失）を多く指摘する傾向にあることを示し，意思決定 のバランス（Pros（恩恵）とCons（損失）のバランス） （32）が，変容のステージによって変化することを明らか にした。間食行動についても同様に，变容のステージに 上る意思決定バランスの変化が予測される。高校生と大 学生に対寸る健康教育に打いては, 間食習慣と間食行動 の変容の意図を調查するとともに，不適切な間食習慣を 有し変容の意図に乏しい者に対して支援策を講じること が必要である。具体策としては, 栄養学, 生理学, 疫学 等の根拠に基づき, 食と健康についての知識を習得させ, 間食をしないことのCons（損失）よりも Pros（恩恵）を 多く指摘できるよう支援することなどが考光られる。

女子高校生及び非一人暮らしの女子大学生に和いて は，食べることを気分転換の手段としている者ほど間食

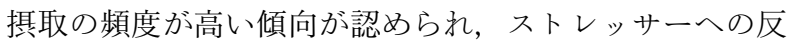
応として間食行動が促進される可能性が考光られた。ス トレッサーへの反応は，健全な習慣の促進と抑制の両方 に関係 (33) していることから, 抑制にかかわる間食の代 替行動を学習することで，健康行動を促進することが大 切である。より健康的な気分転換法について学習し，そ の意義を認識することが間食行動を回避するための有効 な手立てであると思われる。

\section{4. 今後の課題}

本研究で使用した質問紙においては, 生徒・学生の居 住地域に関する質問項目を設けていないことから，都市 
型地域や農村傾向の地域等, 地域性を考慮した分析を行 らことができない。したがって, 学校の所在地域や生徒・ 学生の居住地域，それぞれのファーストフード店及びュ ンビニの店舗数等を踏まえて食行動に影響を与える食物 啫好及び社会心理的要因について検討することを今後の 課題としたい。

\section{V 結 論}

高校生及び大学生を対象に行った食行動, 食物嗜好, 心理社会的ストレス，食の外部化，健康に関する意識， 情報的影響等に関する質問紙調査の結果に基づき，食行 動に影響を与える要因について検討を行った。分析の結 果, 食行動, 食物嗜好, 社会心理的要因の相互関連につ いて，以下の知見が得られた。

1. 高校生及び大学生の各男女別で因子分析を行った結 果, いずれの群に打いても「間食の嗜好」,「間食摂取」, 「インスタント食品・コンビニ食・ファーストフード摂 取理由」の項目間に関連性が認められた。扣菓子やス ナック類が好きな者ほど, 昼食から夕食の間や夕食後, 空腹時に一人で間食する頻度が高く，間食が習慣化し ている傾向が示唆された。また，これらの食物嗜好・ 間食行動は，インスタント食品・コンビニ食・ファー ストフードに好きな品・メニューがあることや品に よっては栄養があるといった，既製品・外食利用に対 する意図と関連があることが示された。

2. 女性は男性と異なり, 学校種別にかかわらず「食事 による気分転換」の項目が，「間食の嗜好」「「間食摂取」, 「揚げ物・炒め物・肉料理の嗜好」の項目と中位の相関 を示した。気分転換を目的に食事をする女子高校生及 び非一人暮らしの女子大学生は，扣菓子，スナック類， 揚げ物，炒め物などの高カロリ一食を好み，間食を頻 繁に行ら傾向にあることが示された。

3.「対人関係・学業ストレス」の項目は, 男子高校生と 女子高校生の両群において，「欠食理由」及び「栄養摂 取」の項目との弱い相関関係を示した。高校生におい ては，朝食欠食の頻度が高く，栄養摂取（栄養バラン ス，家庭料理の摂取等）得点の低い者の方が，対人関 係・学業に関するストレス意識が高い傾向にあること が示された。

以上, 高校生及び大学生の食物摂取, 食物嗜好, 社会 心理的要因の相関構造から，1）高校生, 大学生の間食行 動には食物嗜好，既製品・外食利用に関する意図が影響 している可能性がある，2）女性は男性に比べて気分転換 を目的とした間食を行ら傾向が強い，3）朝食欠食, 栄養 のバランスや家庭料理の欠如は, 高校生の対人関係や学 業面での心理的ストレスを高める可能性があることが考 えられた。
謝辞

本研究の遂行に当たり，貴重なご助言をくださいまし た名桜大学の杉本英夫名誉教授，東北大学大学院教育学 研究科の柴山直教授, 元新潟大学大学院現代社会文化研 究科の故本田仁視教授に心から感謝を申し上げます。

\section{文献}

（1）健康日本 21 企画検討会, 健康日本 21 計画策定検討会. 健康日本 21 (21 世紀に打ける国民健康づくり運動につ いて）健康日本 21 企画検討会, 健康日本 21 計画策定 検討会報告書. 東京 : 財団法人 健康・体力づくり事業 財団, 2000

（2）内閣府.「平成 23 年版食育白書 (本編) PDF 形式 $\rfloor 2011$. http://www8.cao.go.jp/syokuiku/data/whitepaper/2011/pdfhonbun.html (Accessed March 1, 2012)

（3）厚生労働省．国民健康・栄養の現状：平成 20 年厚生労 働省国民健康・栄養調査報告より。東京：第一出版, 2011:72-85.

(4) Shepherd R. Psychological aspects of food choice. Food Sci Technol Today 1995;9:178-182.

( 5 ) Story M, Neumark-Sztainer D, French S. Individual and environmental influences on adolescent eating behaviors. J Am Diet Assoc (Suppl) 2002;102:s40-s51.

（6）池田順子，浅野弘明，永田久紀. 女子学生の食生活の 実態（第 1 報）: 栄養摂取状況に関する居住形態と意識 調査からの検討. 栄養学雑誌 1983;41:103-116.

（7）伊海公子，坂本裕子，三好正満.下宿女子大生の生活 環境と食生活型。栄養学雑誌 1997;55:239-251.

（8）伊海公子，坂本裕子，三好正満.下宿女子大生の食生 活と生活要因との関連 : 食生活上の改善点・困惑点か ら. 栄養学雑誌 1999;57:11-24.

（9）笠巻純一．高校生・大学生の食行動に影響を与える要 因の検討. Health Behav Sci 2011;10:19-31.

（10）門田新一郎. 高校生の健康習慣に関する意識，知識, 態度について: 食物摂取頻度調査との関連. 栄養学雑 誌 2004;62:9-18.

（11）伊海公子．情報源が食生活に与える影響．家政学研究 1995;41:71-83

（12）白木まさ子，岩嵉奈穂美. 大学生の食生活に及ぼす欠 食の影響について．栄養学雑誌 1986;44:257-265.

（13）浅野真智子，深蔵紀子，尾立純子，瓦家千代子，難波 敦子，安田直子，山本悦子．児童から大学生にいたる 若年者層のファーストフードの利用実態調査. 栄養学 雑誌 $2003 ; 61: 47-54$

（14）難波敦子，尾立純子，浅野真智子，瓦家千代子，島田 豊治，深蔵紀子，安田直子，山本悦子、コンビニエン ス・ストアーの利用の実態と食生活状況．栄養学雑誌 2001;59:135-145.

（15）今田純雄. 第 7 章 青年期の食行動。中島義明，今田純 雄編，たべる食行動の心理学．東京：朝倉書店，1996: 114-131.

(16) Drewnowski A, Henderson SA, Levine A, Hann C. Taste and food preferences as predictors of dietary practices in young women. Public Health Nutr 1999;2:513-519. 
(17) Kalish S. Your child's fitness: Practical advice for parents. Champaign, Illinois: Human Kinetics, 1996:167-173.

（18）梶岡多恵子, 大沢 功, 吉田 正, 佐藤祐造. 女子高 校生に打ける正常体重肥満者に関する研究：いわゆる “隠れ肥満者” の身体的特徵とライフスタイルについ て. 学校保健研究 1996;38:263-269.

（19）卜蔵浩和, 小黒浩明, 山口修平, 飯島献一, 高橋一夫, 豊田元哉, 渡辺達三, 小林祥泰. 極端な偏食により脚 気をくり返した 1 例. 島根医学 2005;25:65-68.

（20）村田 敬, 伊藤佳代子, 高木洋子, 森 栄作, 安藤理 子，中川内玲子，阿部 恵，河野茂夫，山田和範，葛 谷英嗣. ビタミン $\mathrm{B}_{1}$ 欠乏症による歩行障害を呈した 2 型糖尿病の 1 例． 糖尿病 2008;51:845-848.

(21) Breslow L, Enstrom JE. Persistence of health habits and their relationship to mortality. Prev Med 1980;9:469-483.

（22）飯田文子, 高橋智子, 川野亜紀, 渡辺敦子, 大越ひろ, 三輪里子. 大学生の食生活の意識について. 日本食生 活学会誌 2001;12:167-175.

（23）山口和子，高橋史人. 食品の嗜好に関する研究（第 2 報）: 属性と食品の好みの関係. 調理科学 1982;15:104113.

（24）財団法人日本学校保健会. 平成 20 年度児童生徒の健康 状態サーベイランス事業報告書. 東京: 財団法人日本 学校保健会, 2010 .

（25）高田裕志，中野弘一. ストレスと食欲. 臨床栄養 1990; 76:136-141.

（26）鈴江緑衣郎．ストレスと栄養. Medicina 1980;17:950-
953.

（27）川畑徹朗，石川哲也，近森けいこ，西岡伸紀，春木 敏, 島井哲志. 思春期のセルフエスティーム, ストレ ス対処スキルの発達と危険行動との関係. 神戸大学発 達科学部研究紀要 2002;10:83-92.

（28）春木 敏. ライフスキル形成に基礎を置く食生活教育 プログラムの開発と評価に関する研究. 神戸大学博士 論文一学術, 乙3 $3020,2009$.

(29) Rampersaud GC, Pereira MA, Girard BL, Adams J, Metzl JD. Breakfast habits, nutritional status, body weight, and academic performance in children and adolescents. J Am Diet Assoc 2005; 105:743-760.

(30) Prochaska JO, DiClemente CC. Stages and processes of self-change of smoking: Toward an integrative model of change. J Consult Clin Psychol 1983;51:390-395.

(31) Prochaska JO, Velicer WF, Rossi JS, Goldstein MG, Marcus BH, Rakowski W, Fiore C, Harlow LL, Redding CA, Rosenbloom D, Rossi SR. Stages of change and decisional balance for 12 problem behaviors. Health Psychol 1994;13:39-46.

(32) Janis IL, Mann L. Decision Making: A psychological analysis of conflict, choice, and commitment. New York: The Free Press, 1977.

(33) Glanz K, Rimer BK, Lewis FM. Health behavior and health education, 3rd Edition. San Francisco: Jossey-Bass, 2002: 210-239. 
日衛誌 (Jpn. J. Hyg.) 第 68 巻 第 1 号 2013 年 1 月

付表 1-1 質問項目と配点

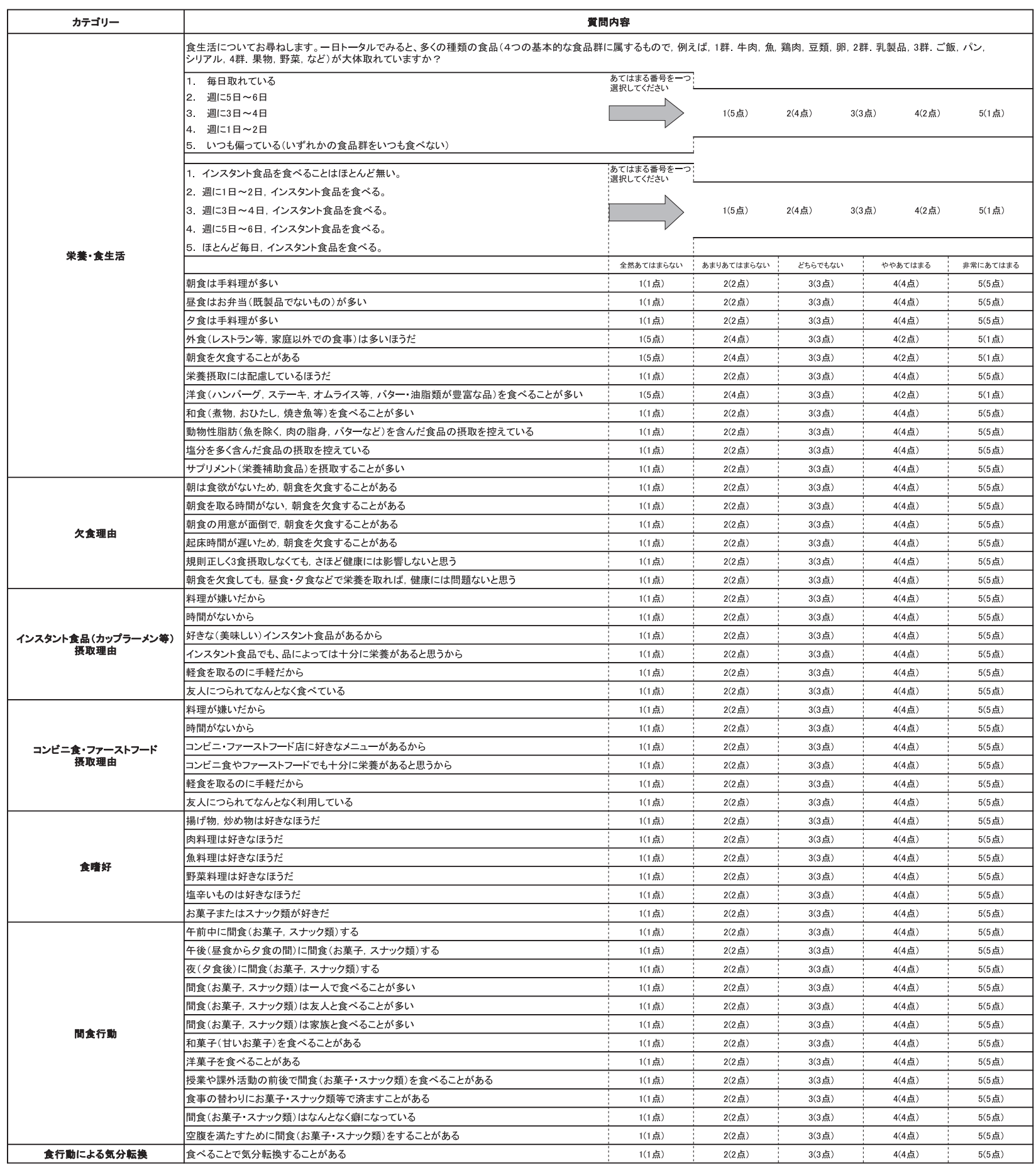


日衛誌 (Jpn. J. Hyg.) 第 68 巻 第 1 号 2013 年 1 月

付表 1-2 質問項目と配点

\begin{tabular}{|c|c|c|c|c|c|c|}
\hline カテゴリー & & & & & & \\
\hline \multirow{14}{*}{ 心理社会的ストレス } & & 全然あてはまらない & あまりあてはまらない & とちらでたな & やややあてはまるる & 非常に:あてはまる \\
\hline & 体重·体脂肪率が高いことが気になる & $1(1$ 点 $)$ & $2(2$ 点 $)$ & $3(3$ 点 $)$ & $4(4$ 点 $)$ & $5(5$ 点 $)$ \\
\hline & 体重·体脂肪率が低いことが気になる & $1(1$ 点 $)$ & $2(2$ 点 $)$ & $3(3$ 点 $)$ & $4(4$ 点 $)$ & $5(5$ 点 $)$ \\
\hline & 学業面でストレスを感じる & 1(1点) & $2(2$ 点 $)$ & $3(3$ 点 $)$ & $4(4$ 点 $)$ & $5(5$ 点 $)$ \\
\hline & 友人との人間関係にストレスを感しる & $1(1$ 点 $)$ & $2(2$ 点 $)$ & $3(3$ 点 $)$ & $4(4$ 点 $)$ & $5(5$ 点 $)$ \\
\hline & 部活動での人間関係にニストレスを感じる & 1(1点) & $2(2$ 点 $)$ & $3(3$ 点 $)$ & $4(4$ 点 $)$ & $5(5$ 点 $)$ \\
\hline & 学校におおける先生との人間関係にストレスを感しる & $1(1$ 点 $)$ & $2(2$ 点 $)$ & $3(3$ 点 $)$ & $4(4$ 点 $)$ & $5(5$ 点 $)$ \\
\hline & 学校以外の社会活動におけける人間関係にスストレスを感しる & 1 (1点) & $2(2$ 点 $)$ & $3(3$ 点 $)$ & $4(4$ 点 $)$ & $5(5$ 点 $)$ \\
\hline & 家族との人間関係でストレスを感じる & $1(1$ 点 $)$ & $2(2$ 点 $)$ & $3(3$ 点 $)$ & $4(4$ 点 $)$ & $5(5$ 点 $)$ \\
\hline & 進路について考えるとき不安を感しる & $1(1$ 点 $)$ & $2(2$ 点 $)$ & $3(3$ 点 $)$ & $4(4$ 点 $)$ & $5(5$ 点 $)$ \\
\hline & 将来に二不安を感じる & $1(1$ 点 $)$ & $2(2$ 点 $)$ & $3(3$ 点 $)$ & $4(4$ 点 $)$ & $5(5$ 点 $)$ \\
\hline & 経済面 (自らの家計) で不安を感じる & $1(1$ 点 $)$ & $2(2$ 点 $)$ & $3(3$ 点 $)$ & $4(4$ 点 $)$ & $5(5$ 点 $)$ \\
\hline & 生活のリズム(学校・バイト・余睱·睡眼など)ににストレスを感じる & $1(1$ 点 $)$ & $2(2$ 点 $)$ & $3(3$ 点 $)$ & $4(4$ 点 $)$ & $5(5$ 点 $)$ \\
\hline & 住居や近所の環境にストレスを感じる & $1(1$ 点 $)$ & $2(2$ 点 $)$ & $3(3$ 点 $)$ & $4(4$ 点 $)$ & $5(5$ 点 $)$ \\
\hline \multirow{8}{*}{ 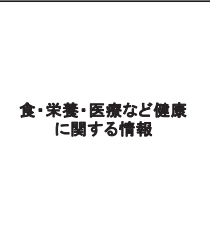 } & 家族から情報を得ている & 1(1点) & $2(2$ 点 $)$ & $3(3$ 点 $)$ & $4(4$ 点 $)$ & $5(5$ 点 $)$ \\
\hline & 友人から情報を得ている & $1(1$ 点 $)$ & $2(2$ 点 $)$ & $3(3$ 点 $)$ & $4(4$ 点 $)$ & $5(5$ 点 $)$ \\
\hline & 学校での授業等で情報を得ている & $1(1$ 点 $)$ & $2(2$ 点 $)$ & $3(3$ 点 $)$ & $4(4$ 点 $)$ & $5(5$ 点 $)$ \\
\hline & 保健·医療機関、健康增進施設で情報を得ている & $1(1$ 点 $)$ & $2(2$ 点 $)$ & $3(3$ 点 $)$ & $4(4$ 点 $)$ & $5(5$ 点 $)$ \\
\hline & テレビ•ラジオから情報を得ている & $1(1$ 点 $)$ & $2(2$ 点 $)$ & $3(3$ 点 $)$ & $4(4$ 点 $)$ & $5(5$ 点 $)$ \\
\hline & インターネット（Webサイト）から情報を得ている & 1(1点) & $2(2$ 点 $)$ & $3(3$ 点 $)$ & $4(4$ 点 $)$ & $5(5$ 点 $)$ \\
\hline & 書籍(雑誌含む)から情報を得ている & $1(1$ 点 $)$ & $2(2$ 点 $)$ & $3(3$ 点 $)$ & $4(4$ 点 $)$ & $5(5$ 点 $)$ \\
\hline & 新聞から情報を得ている & $1(1$ 点 $)$ & $2(2$ 点 $)$ & $3(3$ 点 $)$ & $4(4$ 点 $)$ & $5(5$ 点 $)$ \\
\hline \multirow{3}{*}{ 食行動之疾病の関連性意踣 } & 偏つた栄養拄取によって、病気にかかる率が高まると思う & $1(1$ 点 $)$ & $2(2$ 点 $)$ & $3(3$ 点 $)$ & $4(4$ 点 $)$ & $5(5$ 点 $)$ \\
\hline & 欠欠食によっって、病気ににかかる率が高まると思う & $1(1$ 点 $)$ & 2 2(2点) & $3(3$ 点 $)$ & $4(4$ 点 $)$ & $5(5$ 点 $)$ \\
\hline & 間食によって、病気にかかる率が高まると思う & 1 (1点) & $2(2$ 点 $)$ & $3(3$ 点 $)$ & $4(4$ 点 $)$ & $5(5$ 点 \\
\hline
\end{tabular}

※カテゴリーと選択肢の配点は、後から追加 